УДК $78.1 ; 78.02$

DOI:

Микола Ластовецький, викладач-методист Дрогобицького музичного фахового коледжу імені Василя Барвінського, дочент, доиент кафедри музикознавства та фортепіано Дрогобицького державного педагогічного університету імені Івана Франка Зоряна Ластовецька-Соланська, кандидат мистецтвознавства, доцент, доиент кафедри історії музики

Львівської національної музичної академії імені Миколи Лисенка

Степан Соланський, кандидат мистеитвознавства, доиент, доиент кафедр спеціального фортепіано $і$ загального та спеціалізованого фортепіано Львівської національної музичної академії імені Миколи Лисенка

\title{
РЕЦЕПЦЯ ТВОРЧОСТІ ВАСИЛЯ БАРВІНСЬКОГО У МУЗИЧНОМУ ЖИТТІ ДРОГОБИЧА
}

У статті розглянуто різноманітні параметри рецепиії творчості відомого українського композитора Василя Барвінського у музично-мистецькому житті Дрогобича. Проведено оцінку регіональних особливостей сприйняття його діяльності. Виявлено, щуо постать мистия отримала розмаїте вианування у краї. Можна відзначити наявність сформованої інфраструктури творчості В. Барвінського у місті Котермака.

Ключові слова: Василь Барвінський; музичне життя Дрогобича; речепція; інфраструктура творчості, заклад музичної освіти; науковий доробок; виконавська діяльність.

Лim. 5.

Mykola Lastovetsky, teacher-methodologist of the Drohobych Music Professional College named after Vasyl Barvinsky, Associate Professor, Associate Professor of the Musicology and Piano Department Drohobych Ivan Franko State Pedagogical University Zoryana Lastovetska-Solanska, Ph.D. (Art Studies), Associate Professor, Associate Professor of the History of Music Department,

Lviv Mykola Lysenko National Academy of Music

Stepan Solansky, Ph.D. (Art Studies), Associate Professor, Associate Professor of the Special Piano and General and Specialized Piano Departments Mykola Lysenko Lviv National Academy of Music

\section{RECEPTION OF VASYLBARVINSKY'S CREATIVITY IN DROHOBYCH'S MUSICALLIFE}

The article considers various parameters of the reception of the work of the famous Ukrainian composer, pianist, teacher, music critic, music and public figure Vasyl Barvinsky (1888-1963) in the musical and artistic life of Drohobych. It reviles the regional peculiarities of the perception of his activity by the musical community of the region, which is characterized by a steady interest in his life. The artist's figure has received a diverse and multifaceted homage in the city, in accordance with its historical, social, cultural and mental background. The presence of two professional music centers (Music College and the Institute of Music Art) had a positive effect on the spread of traditions of perception, cultivation and dissemination of musical information. It is stated the formed infrastructure of V. Barvinsky's creativity in the Kotermak's city, which has certain forms and characteristic models. These include public recognition, expressed in: naming in honor of the composer the Drohobych College of Music in 1995 on the occasion of the 50th anniversary of its establishment; organization of the V. Barvinsky Scientific and Cultural Society; holding competitions of young pianists named after V. Barvinsky (in 1998 - the First Regional Competition, in 2002 - the Galician Regional Competition, in 2005 - the Ukrainian, in 2008 and 2018 - the International Competition); holding of monographic concerts of V. Barvinsky's works and its constant presence in the city's musical life and in the pedagogical repertoire of educational music institutions; writing works dedicated to the composer ("Elegy to V. Barvinsky (to the 110th anniversary of his birth)" for strings, trombones and timpani (1998) by M. Lastovetsky); organization of scientific conferences and publication of special Barvinsky's studies; opening of the V. Barvinsky's Room-Museum in the College of Music, with a significant collection of manuscripts, photographs, printed publications, audio recordings, etc.; solemn celebration of the anniversaries of the artist's life; holding creative meetings, presentations, exhibitions and other art events, etc. It is stated the significant influence of $V$. Barvinsky on the musical life of the city of Kotermak, worthy of honoring the memory of the composer.

Keywords: Vasyl Barvinsky; musical life of Drohobych; reception; infrastructure of creativity; institutions of music education; scientific works; performing activities. 
ректор Львівської консерваторії Василь Олександрович Барвінський (1888-1963) займає важливе місце в культурно-мистецькому житті Дрогобича. Підтвердженням цього є розвинена інфраструктура його творчості, яка має у місті своєрідні ознаки та виступає віддзеркаленням рецепції доробку мистця музичною громадою краю.

Аналіз основних досліджень і публікацій. Наукову царину Барвінськознавства презентують як дисертації, монографії, так і окремі розвідки. Дотичними до теми означеної статті стали публікації Н. Кашкадамової, Л. Кияновської, Л. Назар-Шевчук, С. Павлишин, Г. Жук та ін. Різні аспекти життєтворчості В. Барвінського дослідили й дрогобицькі науковці, серед яких В. Грабовський, М. Ластовецький [1], I. Бермес, Л. Філоненко [4], С. Дацюк, У. Молчко, О. КовальськаФрайт, О.Німилович,Л.Садова, Л.Соловей,Л.Федоронько, Л.Щурик,М. Ярко[5],Н.Ек[5],М.Каралюс, З. Лельо, Н. Сторонська, Н. Сулій та ін.

Щодо концептів “рецепція композиторської творчості" та "інфраструктура творчості композитора”, які у пропонованій статті апліковані на життєтворчість В. Барвінського, то тут орієнтовано на модель, запропоновану дослідницею С. Олійник при аналізі регіональних особливостей рецепції творчості композиторівромантиків Ф. Шопена, Ф. Ліста та Р. Вагнера в музичній культурі міста Львова [3, 231].

Мета статті - дослідити різновекторні параметри рецепції творчості В. Барвінського у музично-мистецькому житті міста Дрогобича.

Виклад основного матеріалу. В контексті статті варто розглянути питання кореляції В. Барвінського до міста Дрогобича яке у багатьох викликає непроминуще зацікавлення. В основному, візити були зумовлені обов'язками мистця в статусі директора ВМІ ім. М. Лисенка та співпрацею з хором “Дрогобицький Боян”, засновником та диригентом якого був композитор, педагог, музично-громадський діяч, отець Северин Михайлович Сапрун (1897-1950) відомий подвижник музичного життя в Дрогобичі, ініціатор відкриття і директор філії ВМІ імені М. Лисенка в Дрогобичі (1922-1940), засновник та головний редактор часопису “Боян”. На іспити до дрогобицької філії Музичного Інституту ім. М. Лисенка В. Барвінський приїздив двічі на рік, переважно, у товаристві Станіслава Пилиповича Людкевича (1879-1979) - видатного українського композитора, музикознавця, педагога, музично-громадського діяча, який від 1936 р. працював інспектором філій ВМI.

Одним із доказів безпосередньої участі композитора в культурно-мистецькому житті краю стала нещодавно віднайдена світлина 3 приватного архіву заслуженого діяча мистецтв України Юліана Олексійовича Корчинського (1921-1990) - визначного фольклориста, диригента, педагога, композитора, організатора музично-громадського життя, який впродовж 20 років (1950-1970) керував заслуженим Прикарпатським ансамблем пісні і танцю “Верховина”, а після того ще 20 (1970-1990) очолював кафедру хорового диригування музичнопедагогічного факультету ДДПІ ім. І. Франка.

Означена фотографія, якій присвячена публікація М. Ластовецького "Про історію однієї невідомої світлини В. Барвінського і С. Людкевича" (2009) [1], була знайдена після смертіЮ. Корчинського, при перевезенні його домашнього архіву в фонди краєзнавчого музею “Дрогобиччина”. Вона поміщена у виданні “Дрогобиччина - земля Івана Франка” (1993, том 1, с. 723 і с. 801), ії фотокопія зберігається серед експонатів Кімнати-музею В. Барвінського в Дрогобицькому музичному фаховому коледжі його імені. Світлина, зроблена 20 липня 1943 р. в м. Дрогобич після постановки опери Миколи Лисенка “Ноктюрн”, зображає корифеїв західноукраїнської музики ХХ ст. В. Барвінського та С. Людкевича в оточенні акторів Підкарпатського Українського театру, отця С. Сапруна, диригента Богдана П'юрка (1906-1953) та директора Юрія Шерегія (19071990).

Рецепція творчості В. Барвінського у музичномистецькому житті Дрогобича має різноманітні параметри та регіональні особливості, зумовлені сприйняттям його діяльності музичною громадою краю, яка характеризується стійким інтересом до життєтворчості мистця. Наявність у місті низки професійних музичних осередків позитивно впливає на поширення традицій сприйняття, культивування та поширення музичної інформації.

Важливо, що в Дрогобичі вже сформувалася інфраструктура творчості В. Барвінського, 3 певними формами, специфічними моделями та складовими сегментами, до яких можна віднести:

- присвосння імені Василя Барвінського Дрогобицькому музичному училищу (нині Дрогобицький музичний фаховий коледж імені В. Барвінського) рішенням виконкому Львівської обласної Ради народних депутатів № 40 від 01 червня 1995 р. 3 нагоди 50-річчя заснування закладу. Важливо, що у цей період ще неповністю “скресла" багатолітня крига замовчування імені композитора і його творчості, починаючи з років арешту та заслання, і Дрогобич опинився у авангарді процесу відродження імені В. Барвінського у всеукраїнському масштабі; 
- заснування Науково-культурологічного товариства імені В. Барвінського (1995) Голова - М. Ластовецький;

- проведення у місті конкурсів юних піаністів імені В. Барвінського (у 1998 р. Першого обласного конкурсу, у 2002 р. Галицького регіонального конкурсу, у 2005 р. Всеукраїнського, у 2008 р. і 2018 р. - Міжнародного конкурсу). Аналізу витоків та динаміці розвитку цього конкурсу присвячена стаття Ірини Новосядлої, яка розглядає його як вагоме явище в загальнокультурному контексті, 3 позиції репертуарних та виконавських параметрів [2].

У цьому контексті слід зауважити, що до складу журі входили учні В. Барвінського: відомий піаніст, Народний артист України, професор, завідувач кафедри спеціального фортепіано ЛДМА ім. М.В. Лисенка Олег Криштальський (1930-2010), професор Марія Крих-Угляр (19342020), доцент Олексій Максимов (автор навчального посібника "Виховання піаністів за методикою В. Барвінського” (2007) та ін.;

- організацію монографічних концертів 3 mворів В. Барвінського і постійну ̈̈x присутність в музичному житті міста та у педагогічному репертуарі освітніх музичних закладів. Також твори композитора стали обов'язковим пунктом у екзаменаційних програмах студентів, концертних виступах викладачів коледжу та ін.;

- появу присвячених композиторові творів (“Елегія В. Барвінському (до 110-річниці від дня його народження)" для струнних, тромбонів та литавр (1998) М. Ластовецького);

- організацію наукових конференцій та видання спеціальних Барвінськознавчих досліджень

У дрогобицьких видавництвах "Посвіт” і “Коло” побачила світ низка наукових збірників про життєтворчість композитора, зокрема, “Фортепіянна творчість Василя Барвінського” (упоряд. О. Німилович) (2001), “Василь Барвінський. 3 музичнописьменницької спадщини” (упоряд. В. Грабовський) (2004), “Василь Барвінський. Статті. Листи. Спогади” (ред.-упор. В. Грабовський) (2008), “Василь Барвінський у дослідженнях і матеріалах” (ред.-упор. В. Грабовський) (2008), "Василь Барвінський і сучасна українська музична культура" (упоряд. В. Грабовський, Л. Філоненко, О. Німилович) (2012).

Дрогобицькі науковці активно досліджують різні віхи життетворчості В. Барвінського, зокрема, це: В. Грабовський (“В. Барвінський у колі Ревуцьких” (2008), “В. Барвінський та сучасна українська музична культура” (2009),
“Повернення В. Барвінського”(2012); М. Ластовецький (“Деякі зауваги щодо впливу В. Барвінського на формування творчої індивідуальності М. Колесси” (2008), "Про історію однієї невідомої світлини В. Барвінського і С. Людкевича” (2009) [1], “В. Барвінський та М. Колесса: перетин творчих особистостей” (2012), “Через терни - до зірок” (2013), “В. Барвінському - 125 років! “ (2013), "Вшанування постаті В. Барвінського в місті Дрогобичі” (2018), “До питання про “Українську рапсодію” В. Барвінського” (2018), “В. Барвінський в сучасному Дрогобичі (до 25-річчя присвоєння імені композитора Дрогобицькому державному музичному училищу)” (2020); Л. Філоненко (“Два листи В. Барвінського К. Стеценку” (2003), "Українські народні пісні для фортепіано В. Барвінського” (2003), “Мордовська каторга В. Барвінського” (2008), “Три прелюдії В. Барвінського” (2010), “Сторінками “Особової справи” В. Барвінського” (2018) [4], “В. Барвінський Вісімпрелюдій.Дляфортепіано” (разомізО.Німилович) (2019) та ін.); О. Німилович (“Фортепіанна творчість В. Барвінського” (2001), “В. Барвінський. Мініатюри на лемківські народні пісні для фортепіано” (2008), “До історії видань фортепіанних творів В. Барвінського” (2009), "Zasady pedagogiczne Wasyla Barwińskiego przez pryzmat znaczenia tradycji” (2011), “В. Барвінський. Варіації-мініатюри на тему української народної пісні”'(2013); I. Бермес (“В. Барвінський і М. Колесса" (2009); О. Ковальська-Фрайт (“М. Лисенко і В. Барвінський: духовно-творча естафета поколінь” (2009); С. Дацюк (“Патріотично-виховне значення хорової творчості В. Барвінського” (2009); M. Ярко (“Фортепіанні “Обробки колядок і щедрівок” В. Барвінського: інновації художньої обробки фольклорного матеріалу” (2009), “Феномен етнонаціональної собітотожності та питання ментально-архетипної підоснови трансформації принципів академізму (на матеріалі фортепіанної сонати В. Барвінського)” (2009), "Інструментальна творчість В. Барвінського в герменевтичному полі сучасної музикознавчої думки” (2010), “Солоспіви В. Барвінського на тлі модерного етапу національного стилеутворення" (2010); Л. Федоронько ("Форма фуги у фортепіанній творчості В. Барвінського” (2009); Л. Соловей (“Урочистості з нагоди 130-річчя від дня народження В. Барвінського” (2018); Л. Щурик (“В. Барвінський в оновленій експозиції кімнати-музею композитора в Дрогобицькому державному музичному училищі імені В. Барвінського" (разом із Н. Ек) (2009) [5], “Із забуття - у безсмертя” (2017); Н. Ек ("Проблеми інтерпретації дитячих творів для фортепіано В. Барвінського (на 
прикладі збірки “38 українських народних пісень”)" (2018); У. Молчко (“Публіцистичний огляд В. Барвінського "Музичне життя у Празі чеській” (2009), "В. Барвінський в газетному слові Нестора Нижанківського” (2018); М. Каралюс (“Стильові риси модерну у камерно-вокальній творчості В. Барвінського” (2009); Н. Сулій (“Рецепція галицьких різдвяних пісень у збірнику В. Барвінського “Колядки і щедрівки” (2009); 3. Лельо ("Прояви кордоцентризму у творчості В. Барвінського" (2009); Н. Сторонська ("Роль творчої спадщини В. Барвінського в удосконаленні професійної підготовки майбутніх учителів музики” (2009); Л. Грицикк (“Творчий доробок українського композитора В. Барвінського” (2009) та ін.;

- відкриття Кімнати-музею В. Барвінського у приміщенні музичного училища (коледжу) зі значною колекцією документів, рукописних матеріалів, світлин, друкованих видань, часописів, аудіозаписів та ін. Експозиція Кімнати-музею постійно оновлюється та поповнюється. Як зазначає Любов Щурик, особливо вартісними стали експонати, які подарував музею музикознавець, архівіст, бібліограф із США Роман Савицький-молодший (1938-2015), який під час візитів до України музей відвідував тричі. Зокрема, він передав музею ноти, афіші концертів, платівки та записи творів В. Барвінського у виконанні української піаністки Дарії ГординськоїКаранович (1908-1999), німецького органіста Міхаеля Грілля (Michael Grill) та ін. [5, 138];

- урочисте відзначення на міському рівні ювілейних дат життя мистця.

У 1998 р., з нагоди 110-ї річниці від Дня народження композитора, в 2008 р., до 120-ї річниці, і в 2018 р., 130-ї річниці, в Дрогобичі відбулась низка заходів - урочисті академії, концерти, науково-теоретичні конференції, презентації, творчі імпрези та ін. У 2013 р., до 125річчя від народження В. Барвінського, було проведено Фестиваль фортепіанної камерної музики українських композиторів Галичини, а 3 15 до 18 лютого 2018 р. відбувся Перший фестиваль “Українська музика в часі і просторі”, присвячений 130-ій річниці від дня народження В. Барвінського;

- проведення творчих зустрічей. Так, у музичному коледжі відбулись зустрічі з:

- колегами В. Барвінського (М. Колессою, С. Павлишин та ін.),

- учнями композитора та жертвами сталінського ГУЛАГу, які знали його з періоду заслання. Зокрема, з ученицею В. Барвінського, громадською діячкою Галиною Юліанівною
Грабець (1916-2006), яку за участь в українському національно-визвольному русі заарештували у 1947 р. і засудили до 25 років таборів, які вона відбувала у Воркуті та Мордовії. Мисткиня зберегла листування з композитором під час заслання і подарувала коледжу невідомий раніше рукопис присвяченого їй твору “Думка" для скрипки, який у 1996 р. вперше виконав скрипаль Іриней Турканик $[4,82]$. Також Г. Грабець опублікувала спогади про В. Барвінського у “Літописі нескореної України” (Львів, 1993) та у львівському журналі “Дзвін” (1997, ч. 4). Крім того, пам'ятними стали зустрічі із громадськополітичним діячем, публіцистом, учасником ОУНУПА Пантелеймоном Казимировичем Василевським (1922-2014), який передав у Кімнату-музей листи В. Барвінського до Г. Грабець, розшифрував їх та написав анотації, та політв'язнем Бенедієм Грущаком, який відбував заслання разом із композитором;

- проведення презентацій, виставок та іниих мистецьких заходів.

20 лютого 2008 р., в день народження В. Барвінського, в музичному училищі було урочисто відкрито погруддя композитора (скульптор Іван Можак), а також галерею барельєфів визначних західноукраїнських композиторів XIX-XX ст. (Д. Січинського, М. Вербицького, А. Вахнянина, Н. Нижанківського, С. Людкевича, М. Колесси, А. Кос-Анатольського, Р. Сімовича). 30 березня 2018 р., 3 нагоди 130річчя від дня народження В. Барвінського, в коледжі було проведено студентську академію у формі мультимедійної презентації на тему “В. Барвінський - творчість і доля” (керівник проєкту - Л.М. Соловей).

Висновки. У статті доведено, що постать В. Барвінського отримала розмаїте та багатосторонне вшанування у Дрогобичі, відповідно до історичних, соціальних, культурних та ментальних передумов. Варто відзначити наявність у місті сформованої інфраструктури творчості композитора, яка володіє усталеними формами та характерними моделями. Загалом, констатується вагомий вплив В. Барвінського на музичне життя міста Котермака, високодостойне вшануванні пам'яті композитора.

Перспективи подальших розвідок полягають у пошуку невідомих біографічних та документальних матеріалів, пов'язаних з перебуванням В. Барвінського в Дрогобичі.

\section{ЛІТЕРАТУРА}

1. Ластовецький М.А. Про історію однієї невідомої світлини В. Барвінського і С. Людкевича. 
Молодь i ринок: щчомісячний науковопедагогічний журнал. Дрогобич, 2009. № 3 (50) березень. С. 22-26.

2. Новосядла І. Конкурси юних піаністів імені В. Барвінського: витоки та динаміка розвитку. Молодь і ринок: щзомісячний науковопедагогічний журнал. Дрогобич, 2009. № 3 (50) березень. С. 152-156.

3. Олійник С. Регіональні параметри рецепції творчості композиторів-романтиків (на прикладі Ф. Шопена, Ф. Ліста та Р. Вагнера в музичній культурі Львова). Наукові збірки ЛНМА ім. М.В.Лисенка.Вип. 40: Музикознавчий універсум: збірник статей. Львів, 2017. С. 228 240. URL: https://naukovizbirkylnma. files. wordpress.com/2017/11/2017-40-muzykoznavchyjuniversum-22.pdf (дата звернення: 07.11.2021).

4. Філоненко Л. Сторінками “Особової справи” Василя Барвінського. Українська музика: науковий часопис. Львів, 2018. Число 4 (30). C. 75-84. URL: https://ukrmus.files.wordpress.com/ 2020/03/2018-4-n30-09.pdf (дата звернення: 01.11.2021).

5. Щурик Л., Ек Н. Василь Барвінський в оновленій експозиції кімнати-музею композитора в Дрогобицькому державному музичному училищі імені В. Барвінського. Молодь і ринок. щзомісячний науково-педагогічний журнал. Дрогобич, 2009. № 3 (50) березень. С. 136-139.

\section{REFERENCES}

1. Lastovetskyi, M.A. (2009). Pro istoriiu odniiei nevidomoi svitlyny V. Barvinskoho i S. Liudkevycha [About the history of one unknown photo by V. Barvinskyi and S. Liudkevych]. Youth and market". Monthly scientific-pedagogical journal. Drohobych, No.3 (50), pp. 22-26. [in Ukrainian].
2. Novosiadla, I. (2009). Konkursy yunykh pianistiv imeni V. Barvinskoho: vytoky ta dynamika rozvytku [Competitions of young pianists named after V. Barvinskyi: origins and dynamics of development]. "Youth and market". Monthly scientificpedagogical journal. Drohobych, No.3 (50), pp. 152 156. [in Ukrainian].

3. Oliinyk, S. (2017). Rehionalni parametry retseptsii tvorchosti kompozytoriv-romantykiv (na prykladi F. Shopena, F. Lista ta R. Vagnera v muzychnii kulturi Lvova) [Regional parameters of reception of creativity of romantic composers (on the example of F. Chopin, F. Liszt and R. Wagner in the musical culture of Lviv)]. Scientific collections of LNMA named after M.V. Lysenko. Vol. 40: Musicological universe: a collection of articles]. Lviv, pp. 228-240. Available at: https:// naukovizbirkylnma.files.wordpress.com/2017/11/ 2017-40-muzykoznavchyj-universum-22.pdf (Accessed 07 Nov. 2021). [in Ukrainian].

4. Filonenko, L. (2018). Storinkamy "Osobovoi spravy" Vasylia Barvinskoho [Turning over the pages of the "Personal case" of Vasyl Barvinskyi]. Ukrainian music: scientific journal. Lviv, No.4 (30), pp. 75-84. Available at: https:// ukrmus.files.wordpress.com/2020/03/2018-4-n3009.pdf (Accessed 01 Nov. 2021). [in Ukrainian].

5. Shchuryk, L. \& Ek, N. (2009). Vasyl Barvinskyi v onovlenii ekspozytsii kimnaty-muzeiu kompozytora v Drohobytskomu derzhavnomu muzychnomu uchylyshchi imeni V. Barvinskoho [Vasyl Barvinskyi in the updated exposition of the Room-Museum of the composer in Drohobych State Music College named after V. Barvinskyi]. "Youth and market". Monthly scientific-pedagogical journal. Drohobych, No.3 (50), pp. 136 - 139. [in Ukrainian].

Стаття надійшла до редакції 22.11.2021

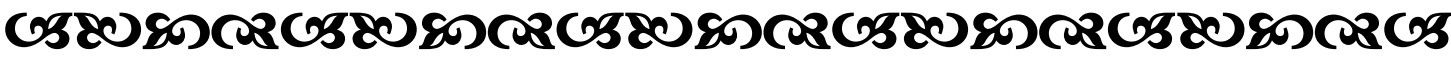

“Музиқа надихає увесь світ, дарує душі қрила, сприяє польоту, уяві; музиқа додає життя $і$ веселощі всьому існуючому.. ІЇ̈ можна назвати втіленням всього преқрасного і всього піднесеного".

$$
\begin{array}{r}
\text { Tлатон } \\
\text { давньогрецький мислитель, ббілософб }
\end{array}
$$

"Музиқа здатна надавати відоме вплив на етичну сторону душі; $і$ раз музика володіє такими властивостями, то, очевидно, вона повинна бути включена в число предметів виховання молоді".

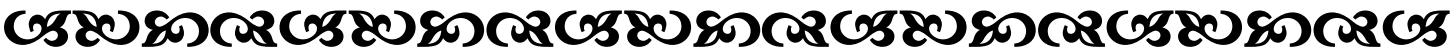

